\title{
Leaf anatomy, ultrastructure and plasticity of Coffea arabica L. in response to light and nitrogen
}

\author{
Marcelo Francisco Pompelli ${ }^{1 *}$ \\ Gilmara Martini Pompelli ${ }^{1}$ \\ Elaine Cristina Cabrini ${ }^{2}$ \\ Maria Claudjane Jerônimo Leite Alves ${ }^{3}$ \\ Marília Contin Ventrella ${ }^{4}$ \\ ${ }^{1}$ Federal University of Pernambuco, Plant Ecophysiology Laboratory \\ Department of Botany, CCB, CEP 50670-901, Recife - PE, Brazil \\ ${ }^{2}$ Federal University of Vales do Jequitinhonha Mucuri, Diamantina - MG, Brazil \\ ${ }^{3}$ Floristic Laboratory of Coastal Ecosystems, Department of Botany, \\ Federal Rural University of Pernambuco, Recife - PE, Brazil \\ ${ }^{4}$ Federal University of Viçosa, Viçosa - MG, Brazil \\ * Corresponding author \\ mpompelli@yahoo.com.br
}

Submetido em 26/10/2011

Aceito para publicação em 28/06/2012

\section{Resumo}

Anatomia foliar, ultra-estrutura e plasticidade de Coffea arabica $\mathrm{L}$. em resposta à luz e nitrogênio. A plasticidade fenotípica em resposta às variações ambientais ocorre em todos os níveis de organização, em escala temporal dentro da mesma espécie vegetal. Entretanto, a magnitude e a significância funcional desta plasticidade são pouco exploradas em espécies perenes. Nós examinamos a influência de diferentes regimes de luz e concentrações de nitrogênio $(\mathrm{N})$ na plasticidade morfofisiológica de plantas jovens de café (Coffea arabica L.). Os experimentos foram realizados em vasos a pleno sol e sob sombra e fertilizados com solução de Hoagland contendo 0, 16 ou $23 \mathrm{mM}$ de N. A maioria das características em reposta à luz demonstram uma clássica distinção entre plantas expostas a pleno sol e sob sombra [e.g. comparadas com as folhas desenvolvidas a pleno sol, as folhas desenvolvidas em $50 \%$ de irradiância tiveram um parênquima paliçádico mais delgado e uma menor massa foliar específica (MFE)]. A parede periclinal externa de ambas as faces da epiderme apresenta uma espessa camada de cera epicuticular, composta por três distintas camadas. Os cloroplastos das células do mesofilo são densamente ocupados por tilacóides, além de grãos de amido facilmente visualizados e essa característica é visualizada de forma mais evidente nas plantas cultivadas com suplemento adicional de nitrogênio e à sombra. $\mathrm{O}$ índice de plasticidade foi alto para as características fisiológicas associadas à fotoproteção e a manutenção de um balanço positivo de carbono nas plantas aclimatadas a sombra, mas foi baixo para a maioria das características morfoanatômicas.

Palavras-chave: Café; Ciclo das xantofilas; Enzimas antioxidantes; Índice de plasticidade

\section{Abstract}

Phenotypic plasticity in response to environmental variation occurs at all organizational levels and across temporal scales within plants. However, the magnitude and functional significance of this plasticity is little explored 
in perennial species. We examined the influence of different light regimes and nitrogen $(\mathrm{N})$ availability on the morphological and physiological plasticity of coffee seedlings (Coffea arabica L.). Potted plants were grown under full sunlight and shade (50\%) and were fertilized with Hoagland's solutions containing 0,16 or $23 \mathrm{mM}$ N. Most leaf traits responded to light with a classic full sunlight vs. shade dichotomy [e.g., compared with those grown under full sunlight, $50 \%$ leaves had a thinner palisade mesophyll and a lower leaf mass per area (LMA) for improved light capture]. The outer periclinal cell walls in both epidermises exhibited thick epicuticular wax and three distinct layers. Chloroplasts of the mesophyll cells were densely occupied by thylakoids and starch grains. These characteristics were observed most clearly in plants supplemented by nitrogen or in those grown in shade conditions. Large starch granules were observed, but no membrane injuries were observed in either treatment. The plasticity index was high for the physiological traits that are associated with photoprotection and the maintenance of a positive carbon balance under shade but was low for most morpho-anatomical features.

Key words: Antioxidant enzymes; Coffee; Plasticity index; Xanthophyll cycle

\section{Introduction}

"Plant species typically segregate across light gradients in the field, giving rise to the light partitioning hypothesis that explains species coexistence in forest ecosystems" (POORTER; ARETS, 2003; VALLADARES et al., 2005). Some plants show sufficient developmental plasticity to respond to a range of light regimes, growing as sun plants in sunny areas and as shade plants in shady habitats. However, other plant species are adapted to either a sunny or a shaded environment (VALLADARES et al., 2005) and show different levels of tolerance to high illumination. Generally, sun plants are better able to sustain exposure to high light than shade plants, which experience photoinhibition (LONG et al., 1994; DURAND; GOLDSTEIN, 2001). However, extensive comparative studies indicate that there are few extremely shadetolerant plants and few extremely light-demanding species, with most species having intermediate, and thus overlapping, light preferences (WRIGHT et al., 2003).

At the leaf level, acclimation may be expressed via morpho-anatomical and physiological adjustments in response to changes in the neighboring (e.g. light) environment (LUSK et al., 2008). We expected that organisms respond primarily via phenotypic plasticity to the environmental changes experienced throughout their lifetime (GRATANI et al., 2006). This ability is a highly important feature of plants because it takes into account, on a spatial and temporal scale, the ability of plants to perceive and respond to different characteristics of different ecosystems. On a temporal scale, this plasticity facilitates survival and a potential specialization of species (ACKERLY, 2003). On the individual level, the expression of phenotypic plasticity is accompanied by the potential for discriminating between environmental qualities that are most suitable for growth (RUBIO-DECASAS et al., 2007).

In coffee plants, two previous studies of plasticity (CHAVES et al., 2008; MATOS et al., 2009) described growth under different light regimes, but leaf expansion was not considered in either study. To best evaluate the effect of light on leaf anatomy, leaf development should be monitored from primordia to mature leaves (FAHN, 1990). The use of leaves without their study, therefore, can generate the wrong results.

Under environmental stress conditions such as nitrogen $(\mathrm{N})$ deficiency, the amount of excess energy can increase as a result of stress-induced decreases in the $\mathrm{CO}_{2}$-fixation capacity (DAMATTA et al., 2002; CRUZ et al., 2004). This lowered capacity means that a plant under a given light intensity may have greater excess energy under N deficiency (VERHOEVEN et al., 1997; DELAGRANGE, 2011).

In this study, we evaluated differences in several morpho-anatomical and physiological/biochemical traits of coffee leaves under contrasting light environments. Special attention was given to changes in leaf thickness, leaf anatomy, and the ultrastructure of the periclinal cell walls and chloroplasts, with a higher cell packing as relative irradiance increased. These questions are 
important for understanding the ecology of coffee plants, because they may reflect the potential of this species to acclimate to changes in light levels as the canopy closes during ecological succession, and they are important for determining the plasticity index of these features.

\section{Material and Methods}

\section{Plant material and experimental design}

The experiment was conducted in Viçosa $\left(20^{\circ} 45^{\prime} \mathrm{S}\right.$, $42^{\circ} 54^{\prime} \mathrm{W}$; 650 m.a.s.1.) in southeastern Brazil. Uniform coffee seedlings (Coffea arabica L. cv 'Red Catuaí IAC 44') with 3 leaf pairs, obtained from seeds, were transplanted (December 2006) into 12-L pots containing a mixture of soil and sand $(2: 1, \mathrm{v} / \mathrm{v})$. After transplanting the seedlings were randomly assigned to one of two light treatments, i.e., plants received either $100 \%$ or $50 \%$ solar radiation here referred to as hight light and low light, respectively. For the low light plants, a shade enclosure was constructed using neutral-density black nylon netting. During the first 45 days after transplanting the plants were fertilized every two weeks with $250 \mathrm{~mL}$ complete Hoagland's nutrient solution (EPSTEIN, 1972), after which they were randomly assigned to one of three nitrogen $(\mathrm{N})$ treatments (January 2007). Irrigation occurred once a week with $250 \mathrm{~mL}$ Hoagland's solution containing 0,16 or $23 \mathrm{mM}$ nitrogen here referred to as $0 \mathrm{~N}, 1 \mathrm{~N}$ or $2 \mathrm{~N}$ plants. Nutrient solutions were supplied until the $0 \mathrm{~N}$ plants had visual symptoms of $\mathrm{N}$ deficiency, particularly in the older leaves. The youngest, fully expanded leaves, corresponding to the third or fourth pair from the apex of the plagiotropic branches, were then sampled and measured (July 2007). Throughout the experiment, the plants were grown under naturally fluctuating conditions of temperature and relative humidity, and they were irrigated with tap water as necessary. During the study period, the means of air temperature, air humidity and rainfall were, respectively, $15.6^{\circ} \mathrm{C}, 84.2 \%$ and $6.3 \mathrm{~mm}$. The locations of the pots were randomized periodically to minimize any spatial variation within each light environment.

The experiment used a completely randomized design, with six treatment combinations, forming a $2 \times$
3 factorial (2 light and $3 \mathrm{~N}$ levels), with one plant per pot, summing 10 plantlets per treatments as replicates. The experimental unit was one plant per container. The experiments were repeated three times with similar results.

\section{Morpho-anatomical features}

The surface area of ten leaves was computed as recommended by Antunes et al. (2008). Each leaf was subsequently oven-dried for $72 \mathrm{~h}$ at $70^{\circ} \mathrm{C}$ and weighed. The leaf mass per area (LMA; g. $\mathrm{m}^{-2}$ ) was then estimated by the leaf mass to surface area ratio.

For anatomical measurements, the mid-laminar areas, excluding the central vein, from ten blade fragments were collected and fixed in $\mathrm{FAA}_{50}$ for $48 \mathrm{~h}$ and then kept in $70 \%(\mathrm{v} / \mathrm{v})$ ethanol. They were then dehydrated in a graded ethanol series and embedded in methacrylate (Historesin-Leica Microsystems Nussloch, Heidelberg, Germany), according to the manufacturer's instructions. Paradermic $(3 \mu \mathrm{m})$ and cross-sections $(7 \mu \mathrm{m})$ were obtained with a rotary microtome (Model RM2155, Leica Microsystems Inc., Deerfield, USA), stained with toluidine blue at pH 4.0 (O'BRIEN et al., 1965) and mounted in synthetic resin $\left(\right.$ Permount $\left.{ }^{\circledR}\right)$. Anatomical data were quantified using image analysis software (Image Pro-Plus, version 4.5, Media Cybernetics, Silver Spring, USA). The materials were analyzed and all images were captured by an Olympus Microscope (AX70TRF, Olympus Optical, Tokyo, Japan). Drawings were traced from photomicrographs. The following anatomical data were collected: (i) total leaf thickness; (ii) palisade and spongy parenchyma thicknesses; (iii) adaxial and abaxial epidermis thicknesses; and (iv) air space, computed as a percentage of the total mesophyll tissue cross-sectional area. Thirty measurements were conducted randomly on 10 light micrographs, for a total of 300 measures per treatment.

\section{Transmission electron microscopy (TEM)}

For the detailed study of the anatomical characteristics of the leaves, several $1-2 \mathrm{~mm}^{2}$ pieces were cut from the mid-laminar areas of coffee leaf blades grown under both high light and low light with 
$0 \mathrm{mM}$ and $23 \mathrm{mM}$ nitrogen (forming a $2 \times 2$ factorial, i.e., 2 light and $2 \mathrm{~N}$ levels). Samples were initially fixed overnight with $2.5 \%$ glutaraldehyde in $0.05 \mathrm{M}$ phosphate buffer ( $\mathrm{pH} 7.0$ ) and post-fixed for $2 \mathrm{~h}$ in $1 \% \mathrm{OsO}_{4}$ in the same buffer at $25^{\circ} \mathrm{C}$. The pieces were dehydrated in a graded ethanol series and then embedded in Spurr resin. Ultrathin sections (100nm thick) were collected in copper grids (300 mesh) and contrasted with uranyl acetate (JUNIPER et al., 1978) followed by lead citrate (REYNOLDS, 1963). All images were acquired using a video camera attached to a Zeiss TEM (Zeiss EM109; Carl Zeiss, Inc., USA). TEM characteristics were observed from 20 electron micrographs per treatment, which were printed at 7,000 and $12,000 \times$ magnifications.

\section{Gas exchange and chlorophyll a fluorescence}

The net carbon assimilation rate $\left(P_{\mathrm{N}}\right)$ and stomatal conductance to water vapor $\left(g_{s}\right)$ were measured with a portable open-flow gas exchange system (LICOR 6400, Li-COR, Lincoln, NE, USA). Measurements were made at midday at ambient temperature and $\mathrm{CO}_{2}$ conditions, under artificial light, i.e., 1,000 and 500 $\mu \mathrm{mol}$ photons $\mathrm{m}^{-2} \cdot \mathrm{s}^{-1}$ at the leaf level, which approximately corresponded to the ambient irradiance intercepted by the sampled leaves (at their natural angles) from the full sunlight and shade plants, respectively. The chlorophyll (Chl) $a$ fluorescence was determined using a portable pulse amplitude modulation fluorometer (FMS2, Hansatech, Norfolk, UK) as described in detail by Pompelli et al. (2010b).

\section{Photosynthetic pigments antioxidant enzymes}

and

Leaf discs $(1.2 \mathrm{~cm}$ diameter) of ten leaves were collected in situ at midday, immediately frozen in liquid nitrogen, and then stored at $-80^{\circ} \mathrm{C}$ until they were analyzed. Chlorophyll and total carotenoids (Car) were extracted using $80 \%(\mathrm{v} / \mathrm{v})$ acetone and quantified spectrophotometrically according to Lichtenthaler (1987). Carotenoids were assayed by HPLC as described by Ramalho et al. (1997), with some modifications. Briefly, pigments were extracted with ice-cold $90 \%$ acetone. The homogenate was then bubbled with gaseous nitrogen, after which it was kept under dark conditions for $30 \mathrm{~min}$ at $4^{\circ} \mathrm{C}$. Subsequently, the homogenate was centrifuged at $15,000 \times g$ for $10 \mathrm{~min}$ at $4^{\circ} \mathrm{C}$, and the supernatant was filtered through a $0.45 \mu \mathrm{m}$ filter before injection into the HPLC (Series 1050, Hewlett Packard, USA). The pigments were separated on an endcapped $\mathrm{C}_{18}$ Spherisorb ODS-2 reversed-phase column (particle size $5 \mu \mathrm{m}, 250 \mathrm{~mm} \times 4.6 \mathrm{~mm}$ ). The elution of carotenoids was performed at $25^{\circ} \mathrm{C}$ over $24 \mathrm{~min}$, with a $0.52 \mathrm{~mL} . \mathrm{min}^{-1}$ flow rate, using an optimized non-linear gradient of $25-100 \%$ ethylacetate in acetonitrile/water [9:1 (v/v), containing $0.1 \%$ triethylamine]. Detection was carried out at 440nm using a UV/VIS detector. For the identification and quantification of peaks, pure commercial standards (VKI, Denmark) were used. The de-epoxidation state of the xanthophyll cycle (DEPS) was calculated as $(\mathrm{Z}+0.5 \mathrm{~A}) /(\mathrm{V}+\mathrm{A}+\mathrm{Z})$, where $\mathrm{Z}$ is zeaxanthin, $\mathrm{A}$ is antheraxanthin and $\mathrm{V}$ is violaxanthin.

Antioxidant enzymes, including superoxide dismutase (SOD; EC 1.15.1.1), ascorbate peroxidase (APX; EC 1.11.1.11), catalase (CAT; EC 1.11.1.6), glutathione reductase (GR; EC 1.6.4.2) and glutamine synthetase (GS; EC 6.3.1.2) were assayed as described by Pinheiro et al. (2004) and Pompelli et al. (2010a).

\section{Plasticity index}

Differences in the plasticity index associated with the morpho-anatomical and physiological/biochemical traits, ranging from 0 (no plasticity) to 1 (maximal plasticity), were calculated as the difference between the minimum and the maximum mean values among the light and nitrogen levels, divided by the maximum mean value (VALLADARES et al., 2000).

\section{Statistical analyses}

The data were statistically analyzed using a fixedmodel ANOVA following a completely randomized design, and significant differences between treatments were determined using the Newman-Keuls test at $\mathrm{P} \leq 0.05$. Mean comparisons were performed using Statistica 7.0 (StatSoft, Inc., Tulsa, OK, USA). 


\section{Results}

\section{Morpho-anatomical features}

The morpho-anatomical traits are shown in Table 1. Light did not have a significant direct or interaction effect on some leaf characteristics, such as total leaf thickness. However, the area of each leaf was significantly smaller (27\%) under high light compared to low light. Overall, the leaves grown in $0 \mathrm{mM} \mathrm{N}$ were smaller than those of their $16 \mathrm{mM}(9.5 \%)$ or $23 \mathrm{mM}(14 \%) \mathrm{N}$ counterparts. LMA and palisade mesophyll thickness increased with increase in photosynthetically active radiation (PAR), whereas the opposite was found for the adaxial and abaxial epidermis thicknesses and the spongy mesophyll air spaces. Nutrient availability affected single leaf area and LMA.
The leaf lamina of coffee plants exhibited an adaxial epidermis of larger cells and an abaxial epidermis of smaller cells. There was an intermediate mesophyll consisting of both palisade and spongy parenchymas (Figure 1). The palisade parenchyma was composed of one layer of elongated cells with small intercellular spaces. However, under high light, the palisade parenchyma was thicker $(7.8 \%)$ than under low light (Table 1).

The cells of the spongy parenchyma had irregular shapes, forming very large intercellular spaces (Figure 2). In both the palisade and spongy parenchymas, the distribution of the chloroplasts was peripheral. The spongy parenchyma air spaces were significantly different between treatments; under low light, plants had a spongy mesophyll that was $12 \%$ less dense than under high light (Figure 2).

TABLE 1: Morpho-anatomical traits [single leaf area, leaf mass per area, total leaf thickness, palisade and spongy thicknesses, upper and lower epidermis thicknesses, air spaces in palisade and spongy mesophylls, and palisade-to-spongy parenchyma ratio (PP:SP)], in the leaves of coffee plants (Coffea arabica L.) under high light or low light with 0N $(0 \mathrm{mM}), 1 \mathrm{~N}(16 \mathrm{mM})$ or $2 \mathrm{~N}(23 \mathrm{mM})$ nitrogen. Different upper case letters represent statistical significance between the means for each light condition, and different lower case letters represent statistical significance among the means of each nitrogen concentration $(P \leq 0.05$, Newman-Keuls test). The values represent the media $( \pm \mathrm{SE})$ of 10 replicates. $\mathrm{ns}=$ not significant.

\begin{tabular}{|c|c|c|c|c|c|c|}
\hline \multirow{2}{*}{ Parameters } & \multicolumn{3}{|c|}{ High light } & \multicolumn{3}{|c|}{ Low light } \\
\hline & $\mathbf{0 N}$ & $1 \mathrm{~N}$ & $2 \mathrm{~N}$ & $\mathbf{0} \mathbf{N}$ & $1 \mathrm{~N}$ & $2 \mathrm{~N}$ \\
\hline Single leaf area $\left(\mathrm{cm}^{2}\right)$ & $38.5 \pm 1.7 \mathrm{Ba}$ & $42.9 \pm 1.5 \mathrm{Ba}$ & $42.2 \pm 6.0 \mathrm{Ba}$ & $46.8 \pm 3.5 \mathrm{Ab}$ & $59.5 \pm 8.6 \mathrm{Aa}$ & $62.9 \pm 2.4 \mathrm{Aa}$ \\
\hline Leaf mass per area $\left(\mathrm{g} \mathrm{m}^{-2}\right)$ & $70.8 \pm 0.8 \mathrm{Ab}$ & $86.8 \pm 2.8 \mathrm{Aa}$ & $89.1 \pm 3.1 \mathrm{Aa}$ & $62.9 \pm 1.3 \mathrm{Bb}$ & $74.2 \pm 2.3 \mathrm{Ba}$ & $69.4 \pm 1.9 \mathrm{Ba}$ \\
\hline Total leaf thickness $(\mu \mathrm{m})$ & $252.1 \pm 12.1 \mathrm{~ns}$ & $264.6 \pm 8.6 \mathrm{~ns}$ & $269.6 \pm 9.8 \mathrm{~ns}$ & $252.0 \pm 6.7 \mathrm{~ns}$ & $248.8 \pm 9.0 \mathrm{~ns}$ & $257.3 \pm 13.8 \mathrm{~ns}$ \\
\hline Palisade thickness $(\mu \mathrm{m})$ & $58.9 \pm 3.3 \mathrm{Aa}$ & $57.6 \pm 2.6 \mathrm{Aa}$ & $60.4 \pm 1.5 \mathrm{Aa}$ & $52.2 \pm 1.1 \mathrm{Ba}$ & $54.0 \pm 2.0 \mathrm{Ba}$ & $57.9 \pm 2.6 \mathrm{Ba}$ \\
\hline Spongy thickness $(\mu \mathrm{m})$ & $152.2 \pm 7.8 \mathrm{~ns}$ & $169.3 \pm 5.8 \mathrm{~ns}$ & $170.0 \pm 9.5 \mathrm{~ns}$ & $155.5 \pm 5.6 \mathrm{~ns}$ & $153.1 \pm 9.6 \mathrm{~ns}$ & $157.0 \pm 10.4 \mathrm{~ns}$ \\
\hline $\begin{array}{l}\text { Adaxial epidermis } \\
\text { thickness }(\mu \mathrm{m})\end{array}$ & $24.2 \pm 0.9 \mathrm{Ba}$ & $22.0 \pm 1.5 \mathrm{Ba}$ & $23.2 \pm 1.3 \mathrm{Ba}$ & $26.5 \pm 0.5 \mathrm{Aa}$ & $24.7 \pm 0.8 \mathrm{Aa}$ & $25.3 \pm 0.8 \mathrm{Aa}$ \\
\hline $\begin{array}{l}\text { Abaxial epidermis } \\
\text { thickness }(\mu \mathrm{m})\end{array}$ & $16.7 \pm 0.9 \mathrm{Ba}$ & $15.7 \pm 0.6 \mathrm{Ba}$ & $15.9 \pm 0.5 \mathrm{Ba}$ & $17.8 \pm 0.9 \mathrm{Aa}$ & $17.0 \pm 0.5 \mathrm{Aa}$ & $17.0 \pm 0.9 \mathrm{Aa}$ \\
\hline Air spaces in palisade $(\%)$ & $10.9 \pm 1.0 \mathrm{~ns}$ & $10.5 \pm 0.8 \mathrm{~ns}$ & $12.3 \pm 1.4 \mathrm{~ns}$ & $12.9 \pm 0.5 \mathrm{~ns}$ & $9.7 \pm 0.4 \mathrm{~ns}$ & $10.1 \pm 0.7 \mathrm{~ns}$ \\
\hline Air spaces in spongy (\%) & $43.2 \pm 1.9 \mathrm{Bb}$ & $46.7 \pm 0.5 \mathrm{Bab}$ & $47.7 \pm 0.8 \mathrm{Ba}$ & $50.6 \pm 0.8 \mathrm{Ab}$ & $51.1 \pm 1.4 \mathrm{Aab}$ & $52.5 \pm 1.6 \mathrm{Aa}$ \\
\hline PP : SP & $0.39 \pm 0.01 \mathrm{~ns}$ & $0.34 \pm 0.02 \mathrm{~ns}$ & $0.36 \pm 0.03 \mathrm{~ns}$ & $0.32 \pm 0.02 \mathrm{~ns}$ & $0.36 \pm 0.03 \mathrm{~ns}$ & $0.37 \pm 0.01 \mathrm{~ns}$ \\
\hline
\end{tabular}


FIGURE 1: Light micrographs of cross-sections of coffee leaves (Coffea arabica L.) grown at different levels of irradiance and nitrogen. Plants were grown under high light (A, C, E) or low light (B, D, F) conditions and at $0 \mathrm{~N}(\mathrm{~A}, \mathrm{~B}), 1 \mathrm{~N}(\mathrm{C}, \mathrm{D})$ or $2 \mathrm{~N}(\mathrm{E}, \mathrm{F})$. AS, air spaces in spongy mesophyll; Cut, cuticle; E, epidermis; PC, palisade cells; s, stomata; SC, spongy mesophyll cells. Bars $50 \mu \mathrm{m}$.

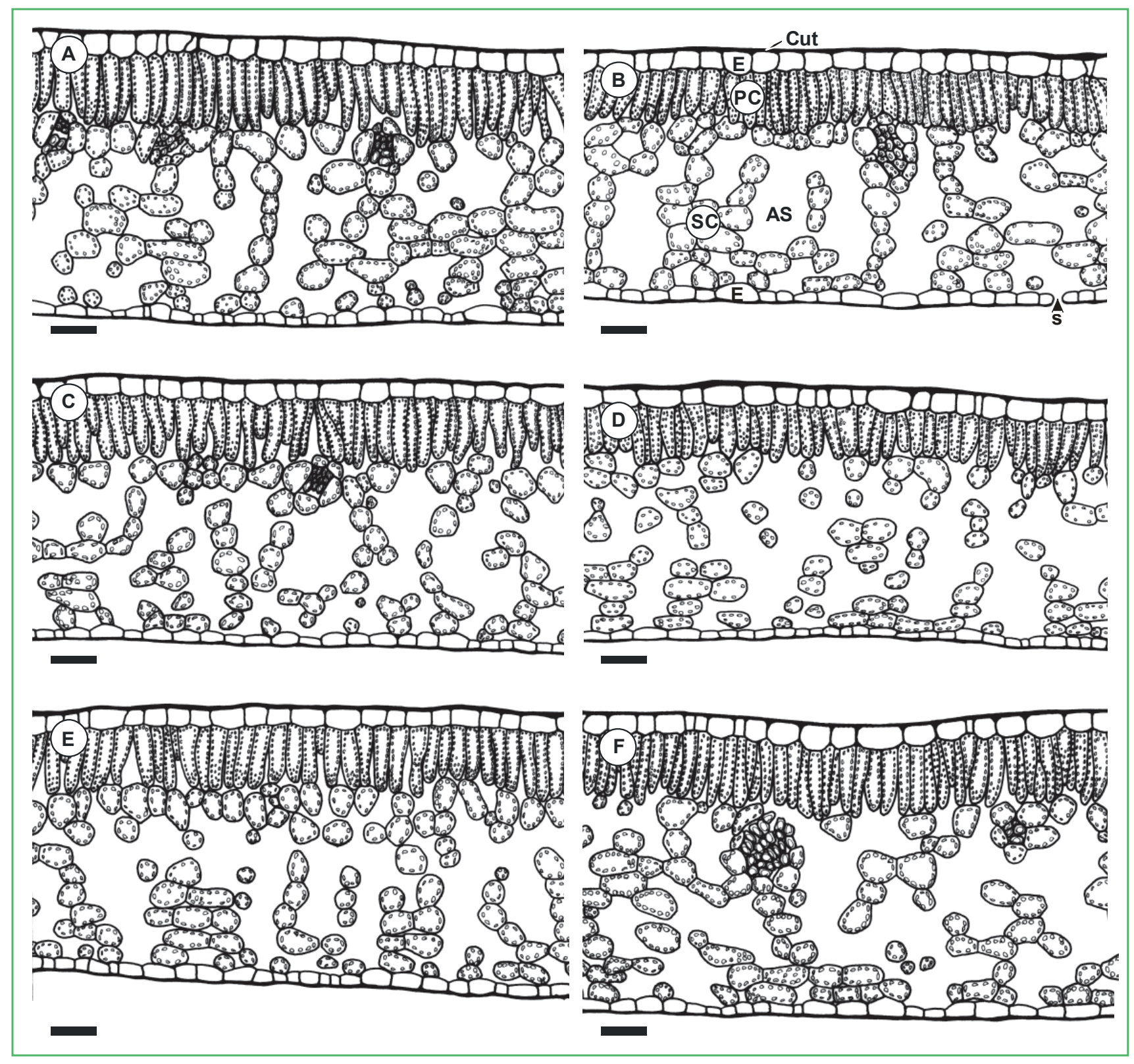


FIGURE 2: Light micrographs of paradermic sections showing the spongy parenchyma of coffee plants (Coffea arabica L.) grown at different levels of irradiance and nitrogen. Plants were grown under high light $(\mathrm{A}, \mathrm{C}, \mathrm{E})$ or low light $(\mathrm{B}, \mathrm{D}, \mathrm{F})$ conditions and at $0 \mathrm{~N}(\mathrm{~A}, \mathrm{~B}), 1 \mathrm{~N}(\mathrm{C}, \mathrm{D})$ or $2 \mathrm{~N}(\mathrm{E}, \mathrm{F})$. Note that the spongy parenchyma of the low light plants was less dense than that of high light plants. AS, air spaces in spongy mesophyll; SC, spongy mesophyll cells. Bars $50 \mu \mathrm{m}$.

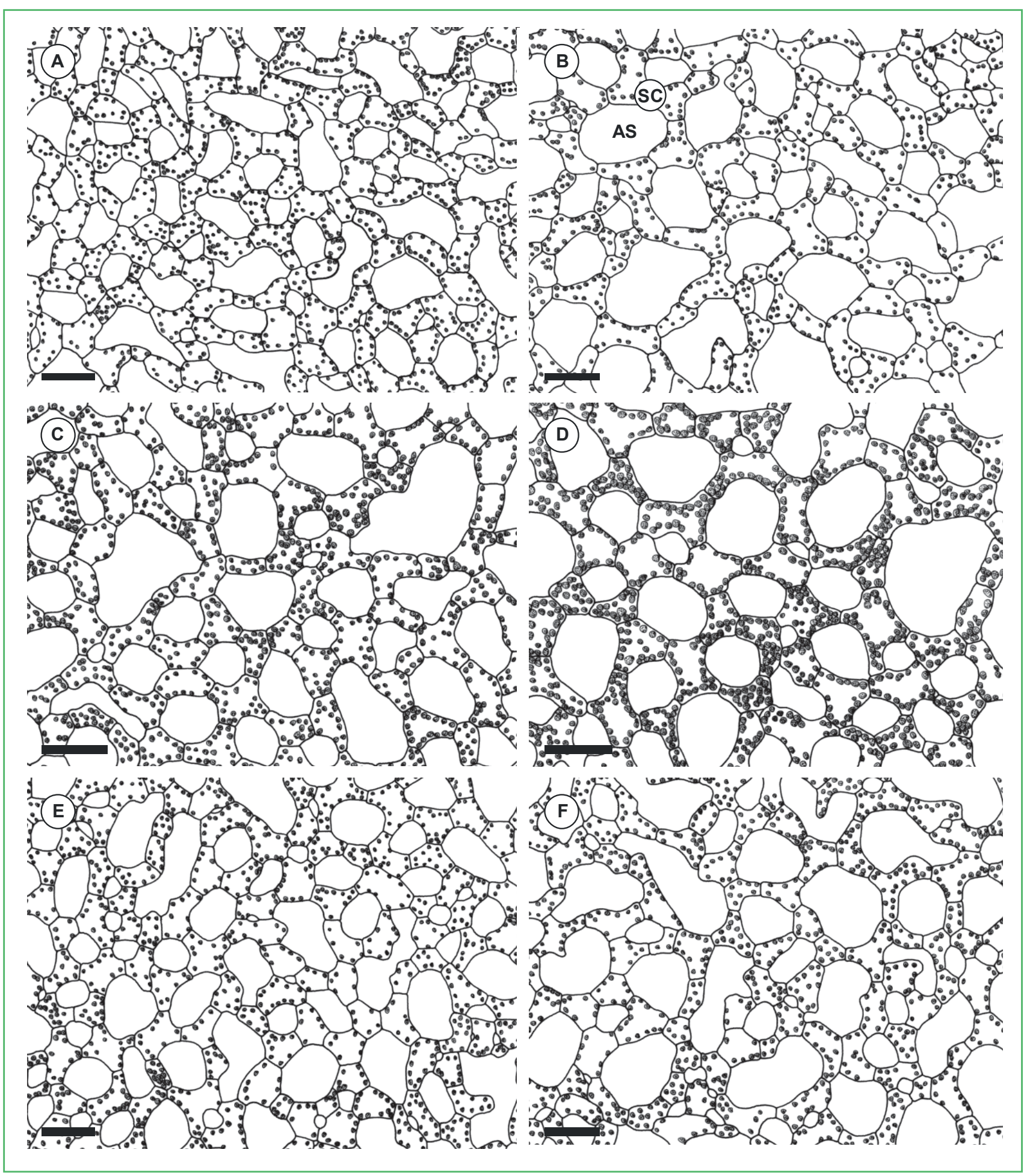




\section{Transmission electron microscopy (TEM)}

In a transverse section of the leaf blade, the adaxial and abaxial epidermis each occurred in a single layer (Figure 1) and were covered with a thick cuticle (Figure 1 and 3). Externally to the cuticle, the epicuticular waxes were present and thicker in high light plants on both the adaxial and abaxial epidermis. The outer periclinal cell walls in both epidermises showed thick epicuticular wax, and three distinct layers were observed: an inner polysaccharide-rich layer mainly composed of cellulose, an intermediate cuticular layer, and a proper cuticle (Figure 3 and 4).

The mesophyll cell chloroplasts were densely occupied by thylakoids. The chloroplasts appeared to be ultrastructurally arranged in grana and stroma lamellae (Figure 5). The lens-shape and dimensions

FIGURE 3: TEM micrographs of the adaxial periclinal cell walls of coffee plants (Coffea arabica $\mathrm{L}$.) grown at different levels of irradiance and nitrogen. Plants were grown under high light $(\mathrm{A}, \mathrm{C})$ or low light $(\mathrm{B}, \mathrm{D})$ conditions and at $0 \mathrm{~N}(\mathrm{~A}, \mathrm{~B})$ or $2 \mathrm{~N}(\mathrm{C}, \mathrm{D})$. Note the irregular deposition of the cuticle on the cell wall (arrows). Cut, cuticle; $\mathrm{CW}$, cell wall; EW, epicuticular wax. Bars $5 \mu \mathrm{m}$.
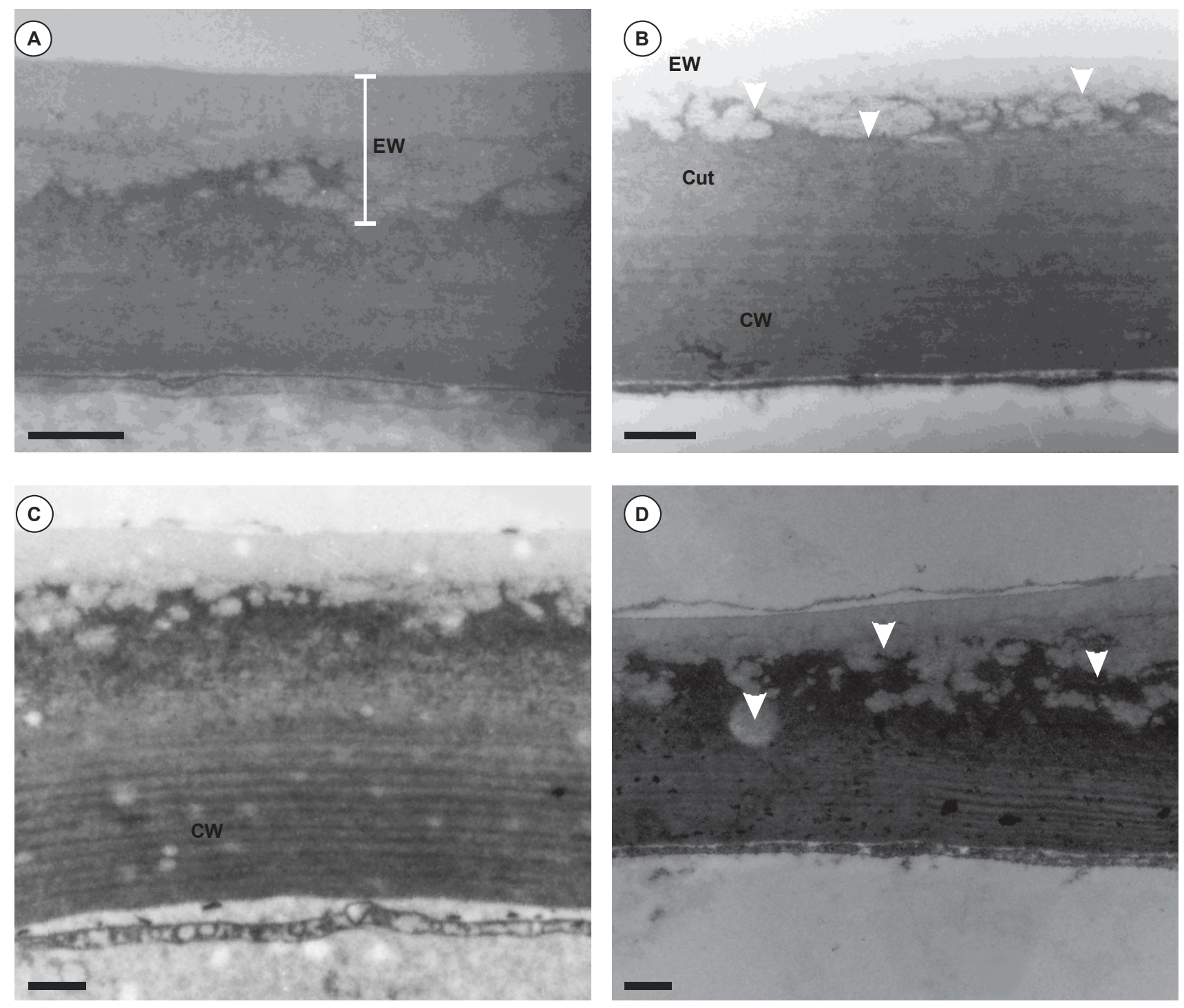
FIGURE 4: TEM micrographs of the abaxial periclinal cell walls of coffee plants (Coffea arabica L.) grown at different levels of irradiance and nitrogen. Plants were grown under high light $(\mathrm{A}, \mathrm{C})$ or low light $(\mathrm{B}, \mathrm{D})$ conditions and at $0 \mathrm{~N}(\mathrm{~A}, \mathrm{~B})$ or $2 \mathrm{~N}(\mathrm{C}, \mathrm{D})$. Cut, cuticle; CW, cell wall; EV, endocitic vesicle; EW, epicuticular wax; PM, plasma membrane. Bars $5 \mu \mathrm{m}$.
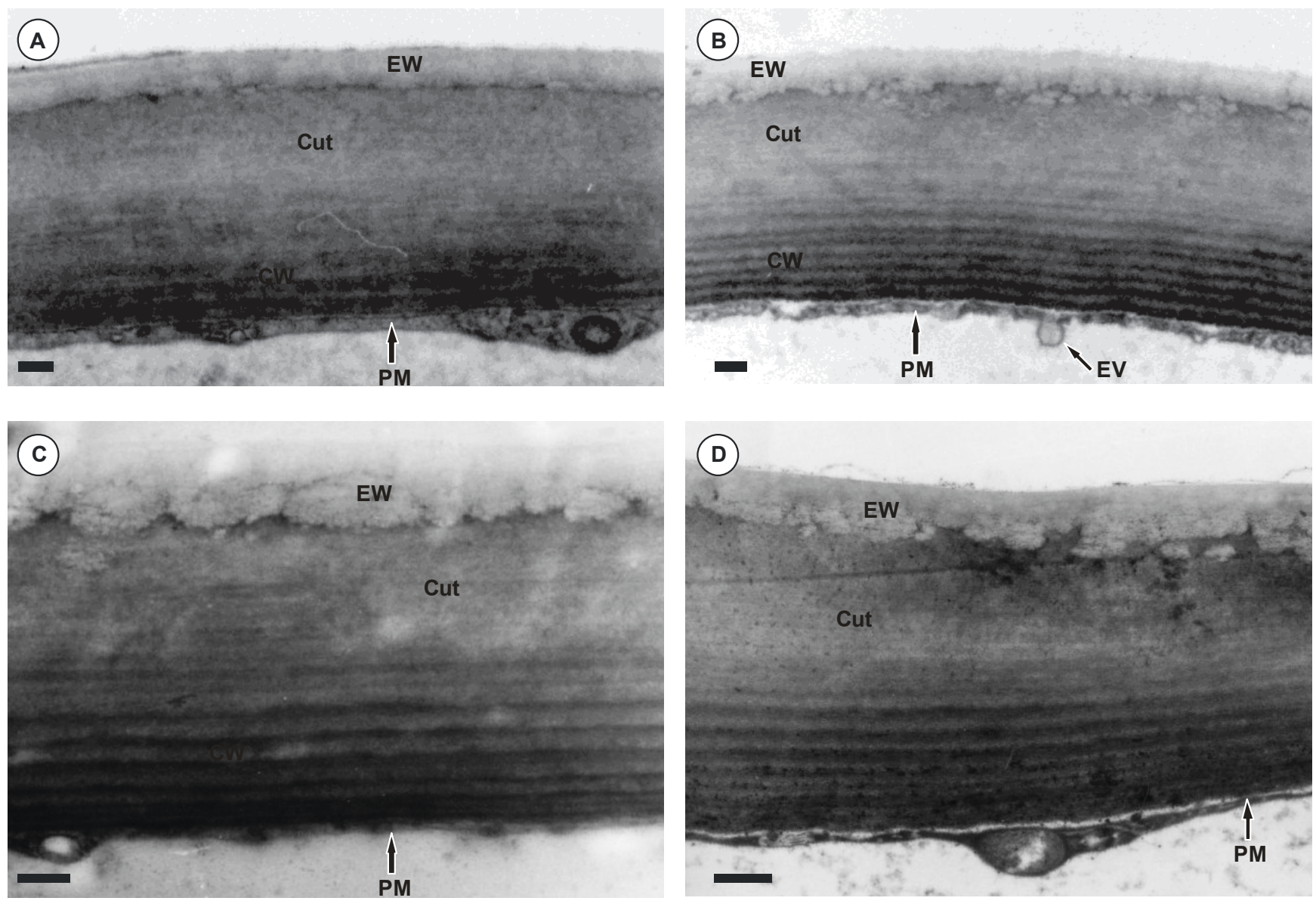

of the chloroplasts did not change across treatments.

reduced nor swollen. However, the grana thylakoids However, a few plastoglobuli were observed in some plants receiving $100 \%$ of full sunlight (Figure 5C), but these characteristics were not associated with photodamage. TEM observation of chloroplasts showed that grana and stroma lamellae were neither significantly of nutrient-rich leaves were more electron-dense than those of nutrient-poor ones, regardless of light treatment. Chloroplasts containing one or more large grain of starch were also identified, mainly in leaves grown in $100 \%$ of full sunlight. 
FIGURE 5: TEM micrographs showing the chloroplast ultrastructure of coffee plants (Coffea arabica L.) grown at different levels of irradiance and nitrogen. Plants were grown under high light (A, C) or low light (B, D) conditions and at $0 \mathrm{~N}(\mathrm{~A}, \mathrm{~B})$ or $2 \mathrm{~N}(\mathrm{C}$, D). Note the regularity of thylakoid stacking and the presence of plastoglobuli (C). S, stroma; St, starch grain; G, granum (stack of thylakoids); CW, cell wall; Stl, stroma lamellae (not stacked); P, plastoglobuli. Bars $2 \mu \mathrm{m}$.
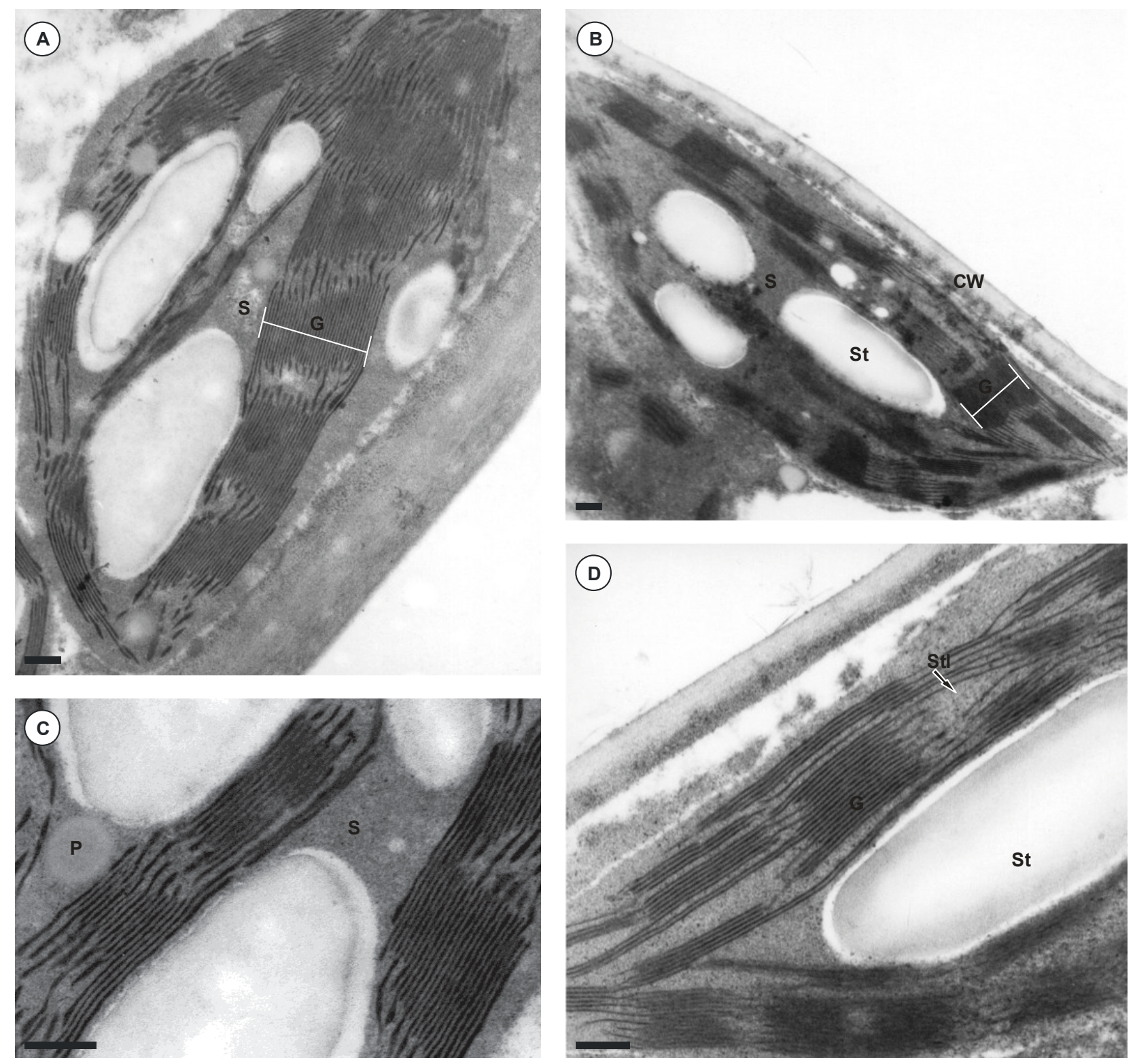

\section{Gas exchange and chlorophyll a fluorescence}

Net carbon assimilation was not affected by nutrient nutrition but was significantly affected by the light availability (Table 2). Irrespective of the treatments, both $P_{\mathrm{N}}$ and $g_{\mathrm{s}}$ were quite low, ranging from 1.47 to $2.21 \mu \mathrm{mol}$ $\mathrm{CO}_{2} \mathrm{~m}^{-2} \cdot \mathrm{s}^{-1}$ and from 10.82 to $18.96 \mu \mathrm{mol} \mathrm{H}_{2} \mathrm{Om}^{-2} \cdot \mathrm{s}^{-1}$, respectively (Table 2). In high light plants, the $F_{\mathrm{v}} / F_{\mathrm{m}}$ ratio

at midday was relatively low and similarly irrespective of the $\mathrm{N}$ level; however, this ratio increased in $2 \mathrm{~N}$ plants relative to $0 \mathrm{~N}$ plants (Table 2). For example, irrespective the $\mathrm{N}$ treatment the $F_{\mathrm{v}} / F_{\mathrm{m}}$ ratio was approximately 0.72 in low light plants compared with 0.67 in high light plants. In dark-adapted leaves, the $F_{\mathrm{v}} / F_{\mathrm{m}}$ at predawn decreased with increasing $\mathrm{A}+\mathrm{Z}$ pools on a $\mathrm{Chl}$ basis and decreased linearly with decreasing $\mathrm{N}$ concentrations (data not shown). 


\section{Photosynthetic pigments}

\section{antioxidant enzymes}

With increasing PAR, Chl $a+b$ decreased from 2.66 (low light leaves) to $1.88 \mathrm{~g} \cdot \mathrm{kg}^{-1} \mathrm{FW}$ (high light leaves). The Car tended to decrease with rising PAR irrespective of $\mathrm{N}$ treatment; however, the $\mathrm{Car} / \mathrm{Chl}$ ratio remained unchanged regardless of the treatments. Independently of the light environment, nutrient-rich plants, compared with their nutrient-poor counterparts, exhibited much larger concentrations per unit mass of neoxanthin (150-197\%), violaxanthin (244-683\%), lutein $(\sim 120 \%)$, $\alpha$-carotene $(214-229 \%)$ and $\beta$-carotene (50-115\%). Concentrations per unit mass of $A$ and $Z$ also tended to be higher $(22-46 \%)$ in nutrient-rich than in nutrient-poor plants, although the differences were only statistically significant for A under low light conditions (Table 2). Within each $\mathrm{N}$ condition, the concentrations of all carotenoids on a mass basis were higher in low light plants than in high light plants, with the exception of A and $\mathrm{Z}$, which were similar between the light treatments.

Expressed per unit mass, the activities of SOD and CAT were not significantly affected by the treatments. GR activities were weakly affected by the treatments, especially in $1 \mathrm{~N}$ plants grown in high light conditions. In contrast, APX activity was lower in 0N plants, particularly under low light regimes (Table 2). GS activity was significantly higher in high light plants than in low light plants at a given $\mathrm{N}$ level and was $\sim 115 \%$ higher in $2 \mathrm{~N}$ plants than in $0 \mathrm{~N}$ plants irrespective of the light treatments.

TABLE 2: Photosynthetic variables [net carbon assimilation $\left(P_{\mathrm{N}}\right)$, stomatal conductance $\left(g_{\mathrm{s}}\right)$ ], fluorescence $\left(F_{\mathrm{v}} / F_{\mathrm{m}}\right)$, concentrations of total chlorophyll (Chl) and total carotenoids (Car) as well as the ratio of $\mathrm{Car} / \mathrm{Chl}$, carotenoid composition and de-epoxidation state of Violaxanthin + Anteraxanthin + Zeaxanthin pool size (DEPS), and activities of SOD (superoxide dismutase), ascorbate peroxidase (APX), catalase (CAT), glutathione reductase (GR) and glutamine syntethase (GS) in the leaves of coffee plants (Coffea arabica L.) under high light or low light and submitted to $0 \mathrm{~N}(0 \mathrm{mM}), 1 \mathrm{~N}(16 \mathrm{mM})$ or $2 \mathrm{~N}(23 \mathrm{mM})$ nitrogen. Different upper case letters represent statistical significance between the means for each light condition and different lower case letters represent statistical significance among the means of each nitrogen concentration $(P \leq 0.05$, Newman-Keuls' test). The values represent the media $( \pm \mathrm{SE})$ of 10 replicates..

\begin{tabular}{|c|c|c|c|c|c|c|}
\hline \multirow{2}{*}{ Parameters } & \multicolumn{3}{|c|}{ High light } & \multicolumn{3}{|c|}{ Low light } \\
\hline & $\mathbf{0} \mathbf{N}$ & $1 \mathrm{~N}$ & $2 \mathrm{~N}$ & $\mathbf{0} \mathbf{N}$ & $1 \mathrm{~N}$ & $2 \mathrm{~N}$ \\
\hline$P_{\mathrm{N}}\left(\mu \mathrm{mol} \mathrm{CO} \mathrm{CO}^{-2} \mathrm{~s}^{-1}\right)$ & $1.47 \pm 0.13 \mathrm{Ba}$ & $1.56 \pm 0.07 \mathrm{Ba}$ & $1.58 \pm 0.14 \mathrm{Ba}$ & $2.12 \pm 0.23 \mathrm{Aa}$ & $2.21 \pm 0.09 \mathrm{Aa}$ & $2.14 \pm 0.25 \mathrm{Aa}$ \\
\hline 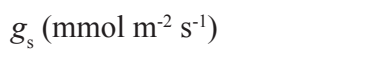 & $18.96 \pm 0.71 \mathrm{Aa}$ & $13.34 \pm 0.45 \mathrm{Ab}$ & $12.21 \pm 0.47 \mathrm{Ab}$ & $13.08 \pm 0.70 \mathrm{Ba}$ & $12.98 \pm 0.50 \mathrm{Aa}$ & $10.82 \pm 1.01 \mathrm{Aa}$ \\
\hline$F_{\mathrm{v}} / F_{\mathrm{m}}$ & $0.65 \pm 0.01 \mathrm{Bb}$ & $0.63 \pm 0.03 \mathrm{Ab}$ & $0.74 \pm 0.01 \mathrm{Aa}$ & $0.75 \pm 0.01 \mathrm{Aa}$ & $0.64 \pm 0.03 \mathrm{Ab}$ & $0.78 \pm 0.02 \mathrm{Aa}$ \\
\hline $\mathrm{Chl}(\mathrm{a}+\mathrm{b})\left(\mathrm{g} \mathrm{kg}^{-1} \mathrm{FW}\right)$ & $1.03 \pm 0.20 \mathrm{Bb}$ & $2.05 \pm 0.13 \mathrm{Ba}$ & $2.56 \pm 0.16 \mathrm{Ba}$ & $1.62 \pm 0.12 \mathrm{Ac}$ & $2.53 \pm 0.47 \mathrm{Ab}$ & $3.82 \pm 0.62 \mathrm{Aa}$ \\
\hline Car $\left(\mathrm{g} \mathrm{kg}^{-1} \mathrm{FW}\right)$ & $0.43 \pm 0.05 \mathrm{Ab}$ & $0.71 \pm 0.04 \mathrm{Aa}$ & $0.88 \pm 0.07 \mathrm{Ba}$ & $0.54 \pm 0.03 \mathrm{Ac}$ & $0.80 \pm 0.08 \mathrm{Ab}$ & $1.20 \pm 0.13 \mathrm{Aa}$ \\
\hline Car/Chl $\left(\mathrm{kg} \mathrm{kg}^{-1} \mathrm{FW}\right)$ & $0.32 \pm 0.05 \mathrm{~ns}$ & $0.30 \pm 0.04 \mathrm{~ns}$ & $0.22 \pm 0.01 \mathrm{~ns}$ & $0.24 \pm 0.03 \mathrm{~ns}$ & $0.24 \pm 0.02 \mathrm{~ns}$ & $0.20 \pm 0.01 \mathrm{~ns}$ \\
\hline Neoxanthin (mg kg-1 FW) & $29.6 \pm 5.2 \mathrm{Ab}$ & $89.2 \pm 17.4 \mathrm{Aa}$ & $87.9 \pm 8.6 \mathrm{Ba}$ & $51.6 \pm 6.4 \mathrm{Ac}$ & $87.2 \pm 7.1 \mathrm{Ab}$ & $129.0 \pm 8.6 \mathrm{Aa}$ \\
\hline Lutein $\left(\mathrm{mg} \mathrm{kg}^{-1} \mathrm{FW}\right)$ & $104.9 \pm 12.1 \mathrm{Ab}$ & $253.9 \pm 42.1 \mathrm{Aa}$ & $235.7 \pm 31.0 \mathrm{Aa}$ & $136.1 \pm 17.0 \mathrm{Ac}$ & $210.5 \pm 17.6 \mathrm{Ab}$ & $298.0 \pm 25.6 \mathrm{Aa}$ \\
\hline Violaxanthin (mg kg $\left.{ }^{-1} \mathrm{FW}\right)$ & $5.4 \pm 1.0 \mathrm{Aa}$ & $14.1 \pm 4.0 \mathrm{Aa}$ & $18.6 \pm 4.5 \mathrm{Ba}$ & $8.0 \pm 1.5 \mathrm{Ac}$ & $33.5 \pm 4.2 \mathrm{Bb}$ & $62.7 \pm 9.0 \mathrm{Aa}$ \\
\hline Anteraxanthin $\left(\mathrm{mg} \mathrm{kg}^{-1} \mathrm{FW}\right)$ & $19.8 \pm 1.7 \mathrm{Aa}$ & $32.1 \pm 8.4 \mathrm{Aa}$ & $24.2 \pm 2.6 \mathrm{Ba}$ & $20.6 \pm 2.9 \mathrm{Ab}$ & $39.3 \pm 6.9 \mathrm{Aa}$ & $53.2 \pm 6.9 \mathrm{Aa}$ \\
\hline Zeaxanthin (mg kg-1 FW) & $96.8 \pm 8.0 \mathrm{Aa}$ & $155.4 \pm 26.4 \mathrm{Aa}$ & $137.4 \pm 29.2 \mathrm{Aa}$ & $83.0 \pm 8.7 \mathrm{Aa}$ & $88.0 \pm 7.6 \mathrm{Ba}$ & $121.1 \pm 19.7 \mathrm{Aa}$ \\
\hline$\alpha$-Carotene $\left(\mathrm{mg} \mathrm{kg}^{-1} \mathrm{FW}\right)$ & $6.5 \pm 1.4 \mathrm{Ab}$ & $23.7 \pm 5.0 \mathrm{Ba}$ & $21.4 \pm 4.0 \mathrm{Ba}$ & $14.5 \pm 1.3 \mathrm{Ac}$ & $33.9 \pm 4.4 \mathrm{Ab}$ & $45.6 \pm 2.4 \mathrm{Aa}$ \\
\hline$\beta$-Carotene (mg kg-1 FW) & $29.7 \pm 4.0 \mathrm{Ab}$ & $60.0 \pm 7.4 \mathrm{Aa}$ & $44.5 \pm 5.5 \mathrm{Ba}$ & $37.2 \pm 3.9 \mathrm{Ac}$ & $62.3 \pm 4.3 \mathrm{Ab}$ & $80.1 \pm 6.9 \mathrm{Aa}$ \\
\hline DEPS & $0.87 \pm 0.01 \mathrm{Aa}$ & $0.85 \pm 0.02 \mathrm{Aa}$ & $0.78 \pm 0.05 \mathrm{Aa}$ & $0.84 \pm 0.02 \mathrm{Aa}$ & $0.68 \pm 0.03 \mathrm{Bb}$ & $0.62 \pm 0.03 \mathrm{Bb}$ \\
\hline $\mathrm{SOD}\left(\mathrm{U} \mathrm{kg}^{-1} \mathrm{FW}\right)$ & $1.01 \pm 0.19 \mathrm{~ns}$ & $1.11 \pm 0.06 \mathrm{~ns}$ & $0.96 \pm 0.04 \mathrm{~ns}$ & $0.86 \pm 0.20 \mathrm{~ns}$ & $1.01 \pm 0.30 \mathrm{~ns}$ & $0.77 \pm 0.17 \mathrm{~ns}$ \\
\hline $\mathrm{APX}\left(\mathrm{U} \mathrm{kg}^{-1} \mathrm{FW}\right)$ & $59.27 \pm 2.60 \mathrm{Ab}$ & $68.97 \pm 4.96 \mathrm{Aa}$ & $71.95 \pm 4.56 \mathrm{Aa}$ & $45.34 \pm 2.87 \mathrm{Bb}$ & $65.07 \pm 5.87 \mathrm{Aa}$ & $73.56 \pm 4.07 \mathrm{Aa}$ \\
\hline CAT (U kg-1 FW) & $2.86 \pm 0.54 \mathrm{~ns}$ & $4.01 \pm 0.89 \mathrm{~ns}$ & $3.93 \pm 0.43 \mathrm{~ns}$ & $2.20 \pm 0.56 \mathrm{~ns}$ & $3.24 \pm 0.34 \mathrm{~ns}$ & $2.70 \pm 0.54 \mathrm{~ns}$ \\
\hline $\mathrm{GR}\left(\mathrm{U} \mathrm{kg}^{-1} \mathrm{FW}\right)$ & $1.75 \pm 0.15 \mathrm{Aab}$ & $1.51 \pm 0.13 \mathrm{Bb}$ & $2.13 \pm 0.18 \mathrm{Aa}$ & $1.78 \pm 0.09 \mathrm{Aa}$ & $2.14 \pm 0.24 \mathrm{Aa}$ & $1.99 \pm 0.18 \mathrm{Aa}$ \\
\hline $\mathrm{GS}\left(\mathrm{U} \mathrm{kg}^{-1} \mathrm{FW}\right)$ & $4.78 \pm 0.33 \mathrm{Ab}$ & $9.82 \pm 0.77 \mathrm{Aa}$ & $10.31 \pm 0.72 \mathrm{Aa}$ & $3.67 \pm 0.25 \mathrm{Ab}$ & $6.80 \pm 0.23 \mathrm{Ba}$ & $7.97 \pm 0.59 \mathrm{Ba}$ \\
\hline
\end{tabular}




\section{Plasticity index}

The plasticity indices of both the morphoanatomical and physiological/biochemical traits under the different treatments are presented in Table 3. On average, the physiological/biochemical characteristics showed significantly (Newman-Keuls test; $\mathrm{p} \leq 0.001$ ) more plasticity $(0.511)$ than the morpho-anatomical traits (0.219). Violaxanthin (0.816), antheraxanthin (0.736) and CAT (0.729), showed high plasticity, indicating that these characteristics are more sensitive and plastic to PAR and $\mathrm{N}$ nutrition than the other measured characteristics (Table 3). Others characteristics, such as APX (0.320), DEPS (0.235) and the $F_{\mathrm{v}} / F_{\mathrm{m}}$ ratio $(0.195)$, showed very low plasticity indices. The $P_{\mathrm{N}}, \mathrm{Car} / \mathrm{Chl}$ ratio, zeaxanthin, $\alpha$-carotene and $\beta$-carotene characteristics showed a moderate plasticity between treatments.

TABLE 3: Plasticity index of morpho-anatomical and physiological/biochemical traits in the leaves of coffee plants (Coffea arabica $\mathrm{L}$.) under high light or low light and submitted to $0 \mathrm{~N}(0 \mathrm{mM}), 1 \mathrm{~N}(16 \mathrm{mM})$ or $2 \mathrm{~N}(23 \mathrm{mM})$ nitrogen. *Denotes statistical significance within morpho-anatomical and physiological/biochemical trais (Newman-Keuls test $P \leq 0.001$ ). Mean values for light and $\mathrm{N}$ nutrition did not differ significantly irrespective of the evaluated traits (Bonferroni's test at $P \leq 0.05$ ).

\begin{tabular}{|c|c|c|c|c|c|c|c|}
\hline \multirow{2}{*}{ Parameters } & \multicolumn{3}{|c|}{ High light } & \multicolumn{3}{|c|}{ Low light } & \multirow{2}{*}{ Mean value } \\
\hline & $\mathbf{0} \mathbf{N}$ & $1 \mathrm{~N}$ & $2 \mathrm{~N}$ & $\mathbf{0} \mathbf{N}$ & $1 \mathrm{~N}$ & $2 \mathrm{~N}$ & \\
\hline \multicolumn{8}{|l|}{ Morpho-anatomical trais } \\
\hline Single leaf area & 0.309 & 0.180 & 0.246 & 0.420 & 0.369 & 0.231 & $0.293 \pm 0.037$ \\
\hline Leaf mass per area & 0.067 & 0.233 & 0.212 & 0.122 & 0.212 & 0.183 & $0.172 \pm 0.026$ \\
\hline Total leaf thickness & 0.216 & 0.169 & 0.165 & 0.145 & 0.191 & 0.254 & $0.190 \pm 0.016$ \\
\hline Palisade thickness & 0.239 & 0.241 & 0.137 & 0.100 & 0.191 & 0.214 & $0.187 \pm 0.023$ \\
\hline Spongy thickness & 0.222 & 0.189 & 0.235 & 0.198 & 0.329 & 0.303 & $0.246 \pm 0.023$ \\
\hline Upper epidermis thickness & 0.179 & 0.309 & 0.240 & 0.099 & 0.157 & 0.141 & $0.188 \pm 0.031$ \\
\hline Lower epidermis thickness & 0.259 & 0.188 & 0.157 & 0.271 & 0.131 & 0.236 & $0.207 \pm 0.023$ \\
\hline Air spaces in palisade & 0.211 & 0.056 & 0.092 & 0.088 & 0.118 & 0.154 & $0.120 \pm 0.023$ \\
\hline Air spaces in spongy & 0.404 & 0.354 & 0.449 & 0.184 & 0.193 & 0.297 & $0.314 \pm 0.045$ \\
\hline $\mathrm{PP}: \mathrm{SP}$ & 0.211 & 0.246 & 0.312 & 0.357 & 0.359 & 0.153 & $0.273 \pm 0.034$ \\
\hline Mean value & $0.232 \pm 0.027$ & $0.217 \pm 0.026$ & $0.225 \pm 0.032$ & $0.198 \pm 0.037$ & $0.225 \pm 0.029$ & $0.217 \pm 0.018$ & $0.219 \pm 0.019$ \\
\hline \multicolumn{8}{|c|}{ Physiological/biochemical trais } \\
\hline$P_{N}$ & 0.561 & 0.368 & 0.609 & 0.664 & 0.331 & 0.658 & $0.532 \pm 0.060$ \\
\hline$g_{\mathrm{s}}$ & 0.341 & 0.273 & 0.296 & 0.372 & 0.248 & 0.512 & $0.340 \pm 0.039$ \\
\hline$F_{\mathrm{v}} / F_{\mathrm{m}}$ & 0.121 & 0.326 & 0.110 & 0.116 & 0.341 & 0.155 & $0.195 \pm 0.044$ \\
\hline $\mathrm{Chl}(\mathrm{a}+\mathrm{b})$ & 0.789 & 0.313 & 0.342 & 0.432 & 0.568 & 0.529 & $0.496 \pm 0.072$ \\
\hline Car & 0.614 & 0.326 & 0.435 & 0.435 & 0.572 & 0.559 & $0.490 \pm 0.045$ \\
\hline $\mathrm{Car} / \mathrm{Chl}$ & 0.771 & 0.559 & 0.528 & 0.613 & 0.567 & 0.091 & $0.532 \pm 0.093$ \\
\hline Violaxanthin & 0.858 & 0.784 & 0.877 & 0.858 & 0.868 & 0.648 & $0.816 \pm 0.036$ \\
\hline Anteraxanthin & 0.534 & 0.811 & 0.610 & 0.803 & 0.895 & 0.763 & $0.736 \pm 0.056$ \\
\hline Zeaxanthin & 0.547 & 0.622 & 0.861 & 0.615 & 0.521 & 0.735 & $0.650 \pm 0.052$ \\
\hline$\alpha$-Carotene & 0.843 & 0.783 & 0.731 & 0.596 & 0.613 & 0.285 & $0.642 \pm 0.081$ \\
\hline$\beta$-Carotene & 0.797 & 0.637 & 0.731 & 0.631 & 0.553 & 0.484 & $0.639 \pm 0.047$ \\
\hline DEPS & 0.119 & 0.127 & 0.382 & 0.168 & 0.300 & 0.314 & $0.235 \pm 0.045$ \\
\hline SOD & 0.694 & 0.252 & 0.233 & 0.807 & 0.922 & 0.661 & $0.595 \pm 0.118$ \\
\hline APX & 0.241 & 0.346 & 0.392 & 0.323 & 0.320 & 0.295 & $0.320 \pm 0.021$ \\
\hline CAT & 0.714 & 0.906 & 0.513 & 0.869 & 0.561 & 0.808 & $0.729 \pm 0.066$ \\
\hline GR & 0.416 & 0.379 & 0.431 & 0.254 & 0.447 & 0.413 & $0.390 \pm 0.029$ \\
\hline GS & 0.338 & 0.441 & 0.368 & 0.378 & 0.201 & 0.423 & $0.358 \pm 0.035$ \\
\hline Mean value & $0.547 \pm 0.060 *$ & $0.485 \pm 0.056^{*}$ & $0.497 \pm 0.052 *$ & $0.525 \pm 0.058^{*}$ & $0.519 \pm 0.053^{*}$ & $0.490 \pm 0.051^{*}$ & $0.511 \pm 0.044$ \\
\hline
\end{tabular}




\section{Discussion}

In general, sun leaves are smaller because the cell arrangement in the mesophyll large surface areas of the cells are exposed and so brought into contact with air, allowing a better loss of latent heat and effective leaf cooling (FAHN, 1990, RUBIO-DE-CASAS et al., 2007). In this study, the spongy parenchyma was denser in leaves grown in high light than in low light leaves (Figure 2). A similar pattern was described by Matos et al. (2009) in adult coffee plants grown under different light regimes.

Leaf mass per area (LMA) is an important parameter in gas exchange modeling because it determines nitrogen partitioning within canopies (VALLADARES et al., 2000). In many cases, nitrogen is distributed along the canopy light gradient to optimize assimilation per unit of nitrogen invested (see ARANDA et al., 2004). Proper adjustments in light capture and the dissipation of excess energy have usually been invoked to explain the lack of an effect of $\mathrm{N}$ deficiency on PSII photochemical efficiency (NUNES et al., 1993; RAMALHO et al., 2003; POMPELLI et al., 2010b). In general, LMA is positively correlated with leaf irradiance and may be considered to be a species-specific estimate of the long-term light conditions that the leaves are exposed to within the canopy (ARANDA et al., 2004 and references therein). Differences in LMA between plant species or ambient light can maximize the change in leaf thickness, the density of leaf tissues, or both (WITKOWSKI; LAMONT, 1991). In the second case, differences are related to an increase in the palisade mesophyll (ESCHRICH et al., 1989). In this study, we showed that an increase in the LMA may be unconnected to the increasing thickness of the leaf, in contrast to the results of Aranda et al. (2004). The differences in LMA between high light and low light leaves were possibly due to an increase in the density of the spongy parenchyma in the high light leaves (Figure 2) compared with their low light counterparts. The relatively less dense spongy parenchyma is especially useful to enhance backscattering of diffuse understory light within the leaf (MARKESTEIJN et al., 2007).

In this study, the periclinal cell walls of plants grown in high light were thicker than those of their low light counterparts. The periclinal cell wall and adaxial epidermis protect the leaf by minimizing the damaging effects of high irradiance through the reflection of excess light (BONDADA et al., 1996). They also reduce cuticular evaporation (EGLINTON; HAMILTON, 1967; MARKESTEIJN et al., 2007) because the biosynthetic pathway for lignin and cutin production is directly dependent on light (JENSEN, 1986). However, the composition, more than the thickness, of the outer periclinal cell wall is important. In general, they are organized into layers of varied composition that are observable using TEM. Moraes et al. (2009), using TEM, reported that they were composed of an inner polysaccharide-rich layer composed mainly of cellulose, an intermediate cuticular layer with a tree-like polysaccharide-rich network immersed in a matrix of cutin, and a cuticle proper layer. The cuticle proper is homogenous and relatively electron-lucent. The cuticular layer is formed by a reticulated network layer and is composed of a cutin matrix and a tree-like layer that is composed of polysaccharides and pectins.

Nutrient-rich leaves exhibited larger starch granules in their chloroplasts (Figure 5). It is worth noting that the samples for anatomical evaluations ware made at 12:00 p.m., when we expected a large allocation of starch in the chloroplast. It should also be noted that the concentrations of starch in the early morning are very low (RONCHI et al., 2006) when the photosynthetic rates of coffee plants are maximal (DAMATTA, 2004). As a consequence, membrane integrity was conserved (Figure 5), and this could be considered to be circumstantial evidence that starch accumulation in the chloroplast was not the primary cause of the lower photosynthetic rates found in this study. In contrast, $\mathrm{N}$ deficiency in citrus leaves can cause both increases (SCHAFFER et al., 1986) or decreases (BONDADA; SYVERTSEN, 2005) in chloroplast starch accumulation. In both cases, the accumulation of starch within the chloroplasts is accompanied by damage and disorientation of the grana and thylakoids (BONDADA; SYVERTSEN, 2005). However, it is not clear how starch impairs chloroplast structure and function (BONDADA; SYVERTSEN, 2005).

Most of the variation in leaf traits could be explained by differences between nitrogen or light environments. 
Although the light effect explained minor variations in leaf traits, high and low light leaves differed in most traits. Carbon fixation is usually the main primary sink for the absorbed PAR in chloroplasts, regardless of $\mathrm{N}$ and irradiance treatments. Adjustments in light capture, use and dissipation are required to provide photoprotection to the photosynthetic apparatus, particularly under $100 \%$ of full sunlight (SIMS; PEARCY, 1989; CAO, 2000; EVANS; POORTER, 2001; MARKESTEIJN et al., 2007). While species differ substantially in their response to differences in light, we found a high correlation between leaf parameters and nitrogen availability (Table 2).

In general, light interacted with nutrient availability in determining the carotenoid content and composition (see POMPELLI et al., 2010b). Because the $\mathrm{N}$ supply affects both the sensitivity to photoinhibition and the production of photoprotective compounds (OSMOND et al., 1997), we expected that nutrient availability would affect photoprotection via the DEPS. The increased carotenoid content of nutrient-rich plants could reflect enhanced photoprotection promoted by $\mathrm{N}$ nutrition (RAMALHO et al., 1997; 2000), whereas the increased Chl content in plants receiving $50 \%$ of full sunlight, regardless of $\mathrm{N}$ nutrition, could reflect enhanced light harvesting (POMPELLI et al., 2010b).

The activity of CAT, an important enzyme in the photorespiratory pathway, is much more responsive to light availability than to $\mathrm{N}$ nutrition. However, the activity of GS, an enzyme that is thought to catalyze the rate-limiting step of photorespiration (OSMOND et al., 1997; TERASHIMA et al., 2006), was remarkably lower in nutrient-poor plants than nutrient-rich plants (i.e., positive correlation; data not shown). This could be considered to be circumstantial evidence that photorespiration has limited importance as an additional sink for excitation energy in the photosynthetic apparatus of nutrient-poor plants (more details in POMPELLI et al., 2010b).

Plants growing under adverse conditions tend to show a conservative pattern even when conditions are temporarily favorable so that they avoid the production of structures too expensive to be sustained once conditions deteriorate (CHAPIN, 1980). These patterns could largely explain why Matos et al. (2009) observed poor physiological plasticity to PAR, as displayed by coffee leaves. Through the combination of morpho-anatomical and physiological/biochemical traits, it was inferred that there is a trade-off between physiological and anatomical plasticities. However, our data do not support the hypothesis that the plasticity index is higher for morphological variables than for physiological variables (VALLADARES et al., 2005). Coffee plants exhibited a moderate to high degree of plasticity in their responses to light or $\mathrm{N}$ availability when considering physiological/biochemical traits. Similar observations have been reported by other investigators (VALLADARES et al., 2000; FUNK et al., 2007; MATOS et al., 2009). In C. arabica, a very low degree of plasticity in leaf morphology in response to irradiance might exacerbate its low adaptability to shade environments when mature (MORAES et al., 2010). A similar feature has been reported for other shade-intolerant species, such as Prunus avium (ARANDA et al., 2004) and Betula pendula (KULL; NIINEMETS, 1993).

The means of plasticity indices presented in this study are larger than those reported by Matos et al. (2009), who used the relative distance plasticity index (RDPI). The use of RDPI is more challenging to calculate and can cause serious problems with pseudoreplication, and thus, it should be used only in specific cases (Fernando Valladares, unpublished information, personal communication). Part of the differences in the plastic response among treatments may be the results of the different methodology used in these studies. Matos et al. (2009) studied adult plants, without considering whether a leaf actually expands under those light regimes. However, in our study, all leaf used to evaluate plasticity was marked even before its primordium. Thus, we conclude that the leaves used in this study actually were grown under high or low light and that light actually affected leaf plasticity (Table 3).

In conclusion, the strategies of the coffee plants were characterized by a low degree of phenotypic plasticity and a relatively high tolerance for excessive radiation, despite coffee's origin as an understory species. In this sense, the physiological/biochemical traits were more sensible, whereas morpho-anatomical plasticity likely plays a secondary role in photoacclimation. That 
seedlings had larger leaves (and a larger leaf area) and were greener (usually indicating a higher Chl concentration) when grown in the shade compared to full sun could give a false perception of greater vigor of the plants. Nonetheless, coffee seedlings grown under full sunlight exhibited better or similar growth relative to plants grown in shade.

\section{Acknowledgements}

The authors would like to thank the National Council for Scientific and Technological Development, CNPq, (Grants 485982/2006-4 and 301313/2007-5) and the Fundação de Amparo a Pesquisa do Estado de Minas Gerais (FAPEMIG) for financial support for this research. The authors would also like to extend special thanks to Mr. Emília Cristina Pereira de Arruda (Plant Anatomy Laboratory - UFPE) for her kind revisions and corrections of this manuscript.

\section{References}

ACKERLY, D. D. Community assembly, niche conservationism, and adaptive evolution in changing environments. International Journal of Plant Science, Chicago, v. 164, n. 1, p. S165-S184, 2003.

ANTUNES, W. C.; POMPELli, M. F.; CARRETERO, D. M.; DAMATTA, F. M. Allometric models for non-destructive leaf area estimation in coffee (Coffea arabica and Coffea canephora). Annals of Applied Biology, Warwick, v. 153, n. 1, p. 33-40, 2008.

ARANDA, I.; PARDO, F.; GIL, L.; PARDOS, J. A. Anatomical basis of the change in leaf mass per area and nitrogen investment with relative irradiance within the canopy of eight temperate tree species. Acta Oecologica, New York, v. 25, n. 3, p. 187-195, 2004. BONDADA, B. R.; OOSTERHUIS, D. M.; MURPHY, J. B.; KIM, K. S. Effect of water stress on the epicuticular wax composition and ultrastructure of cotton (Gossypium hirsutum L.) leaf, bract, and boll. Environmental and Experimental Botany, Paris, v. 36, n. 1, p. 61-69, 1996.

BONDADA, B. R.; SYVERTSEN, J. P. Concurrent changes in net $\mathrm{CO}_{2}$ assimilation and chloroplast ultrastructure in nitrogen deficient citrus leaves. Environmental and Experimental Botany, Paris, v. 54, n. 1, p. 41-48, 2005.

CAO, K. Leaf anatomy and chlorophyll content of 12 woody species in contrasting light conditions in a bornean heath forest. Canadian Journal of Botany, Guelph, v. 78, n. 10, p. 1245-1253, 2000.

CHAPIN, F. S. The mineral nutrition of wild plants. Annual Review of Ecology, Evolution, and Systematics, Palo Alto, v. 11, n. 1, p. 233-260, 1980.
CHAVES, A. R. M.; TEN-CATEN, A.; PINHEIRO, H. A.; RIBEIRO, A.; DAMATTA, F. M. Seasonal changes in photoprotective mechanisms of leaves from shaded and unshaded field-grown coffee (Coffea arabica L.) trees. Trees, Vancouver, v. 22, n. 3, p. 351-361, 2008.

CRUZ, J. L.; MOSQUIN, P. R.; PELACANI, C. R.; ARAÚJO, W. L.; DAMATTA, F. M. Effects of nitrate nutrition on nitrogen metabolism in Cassava. Biologia Plantarum, Praha, v. 48, p. 6772, 2004.

DAMATTA, F. Ecophysiological constraints on the production of shaded and unshaded coffee: a review. Field Crops Research, Weigang, v. 86, n. 2-3, p. 99-114, 2004.

DAMATTA, F. M.; LOOS, R. A.; SILVA, E. A.; LOUREIRO, M. E. Limitations to photosynthesis in Coffea canephora as a result of nitrogen and water availability. Journal of Plant Physiology, Tübingen, v. 159, n. 9, p. 975-981, 2002.

DELAGRANGE, S. Light- and seasonal-induced plasticity in leaf morphology, $\mathrm{N}$ partitioning and photosynthetic capacity of two temperate deciduous species. Environmental and Experimental Botany, Paris, v. 70, n. 1, p. 1-10, 2011.

DURAND, L. Z.; GOLDSTEIN, G. Photosynthesis, photoinhibition and nitrogen use efficiency in native and invasive tree ferns in Hawaii. Oecologia, Heidelberg, v. 126, n. 3, p. 345-354, 2001.

EGLINTON, G.; HAMILTON, R. J. Leaf epicuticular waxes. Science, New York, v. 156, n. 3780, p. 1322-1335, 1967.

EPSTEIN, E. Mineral nutrition of plants: principles and perspectives. New York: John Wiley \& Sons, 1972. 412 p.

ESCHRICH, W.; BURCHARDT, R.; ESSIAMAH, S. The induction of sun and shade leaves of the European beech (Fagus sylvatica L.): anatomical studies. Trees, Vancouver, v. 3, n. 1, p. 1-10, 1989.

EVANS, J. R.; POORTER, H. Photosynthetic acclimation of plants to growth irradiance: the relative importance of specific leaf area and nitrogen partitioning in maximizing carbon gain. Plant, Cell and Environment, Oxford, v. 24, n. 8, p. 755-767, 2001.

FAHN, A. Plant anatomy. 2. ed. Oxford: Butterworth Heinemann, 1990. 588 p.

FUNK, J. L.; JONES, C. G.; LERDAU, M. T. Leaf-and shoot-level plasticity in response to different nutrient and water availabilities. Tree Physiology, Victoria, v. 27, n. 12, p. 1731-1739, 2007.

GRATANI, L.; COVONE, F.; LARCHER, W. Leaf plasticity in response to light of three evergreen species of the Mediterranean maquis. Trees, Vancouver, v. 20, n. 5, p. 549-558, 2006.

JENSEN, R. A. The shikimate/arogenate pathway: link between carbohydrate metabolism and secondary metabolism. Physiologia Plantarum, Lund, v. 66, n. 1, p. 164-168, 1986.

JUNIPER, B. E.; COW, G. C.; GILOHRIST, A. J.; WILLIAMS, P. $\mathrm{K}$. Techniques for plant electron microscopy. Oxford: Blackwell Scientific Publications, 1978. 108 p.

KULL, O.; NIINEMETS, Ü. Variation in leaf morphometry and nitrogen concentration in Betula pendula Roth., Corylus avellana L. and Lonicera xylosteum L. Tree Physiology, Victoria, v. 12, n. 3, p. 311-318, 1993.

LICHTENTHALER, H. K. Chlorophylls and carotenoids: pigments of photosynthetic biomembranes. Methods in Enzymology, Pasadena, v. 148, n. 1, p. 350-382, 1987. 
LONG, S. P.; HUMPHRIES, S.; FALKOWSKI, P. G. Photoinhibition of photosynthesis in nature. Annual Review of Plant Physiology and Plant Molecular Biology, Palo Alto, v. 45, n. 1, p. 633-662, 1994.

LUSK, C.; REICH, P. B.; MONTGOMERY, R. A.; ACKERLY, D. D.; CAVENDER-BARES, J. Why are evergreen leaves so contrary about shade? Trends in Ecology \& Evolution, London, v. 23, n. 6, p. 299-303, 2008.

MARKESTEIJN, L.; POORTER, L.; BONGERS, F. Light-dependent leaf trait variation in 43 tropical dry forest tree species. American Journal of Botany, Saint Louis, v. 94, n. 4, p. 515-525, 2007.

MATOS, F. S.; WOLFGRAMM, R.; GONÇALVES, F. V.; CAVATTE, P. C.; VENTRELlA, M. C.; DAMATTA, F. M. Phenotypic plasticity in response to light in the coffee tree. Environmental and Experimental Botany, Paris, v. 67, n. 2, p. 421-427, 2009.

MORAES, G. A. B. K.; CHAVES, A. R. M.; MARTINS, S. C. V.; BARROS, R. S.; DAMATTA, F. M. Why is it better to produce coffee seedlings in full sunlight than in the shade? A morphophysiological approach. Photosynthetica, Olomouc, v. 48, n. 2, p. 199-207, 2010.

MORAES, T. M. S.; BARROS, C. F.; SILVA NETO, S. J.; GOMES, V. M.; CUNHA, M. Leaf blade anatomy and ultrastructure of six Simira species (Rubiaceae) from the Atlantic Rain Forest, Brazil. Biocell, Mendoza, v. 33, n. 3, p. 155-165, 2009.

NUNES, M. A.; RAMALHO, J. D. C.; DIAS, M. A. Effect of nitrogen supply on the photosynthetic performance of leaves from coffee plants exposed to bright light. Journal of Experimental Botany, Oxford, v. 44, n. 5, p. 893-899, 1993.

O'BRIEN, T.; FEDER, N.; MCCULLY, M. Polychromatic staining of plant cell walls by toluidine blue. Protoplasma, Heidelberg, v. 59, n. 1, p. 368-373, 1965.

OSMOND, B.; BADGER, M.; MAXWELL, K.; BJÖRKMAN, O.; LEEGOOD, R. Too many photons: photorespiration, photoinhibition and photooxidation. Trends Plant Science, Maryland Heights, v. 2, n. 4, p. 119-121, 1997.

PINHEIRO, H. A.; DAMATTA, F. M.; CHAVES, A. R. M.; FONTES, E. P. B.; LOUREIRO, M. E. Drought tolerance in relation to protection against oxidative stress in clones of Coffea canephora subjected to long-term drought. Plant Science, Davies, v. 167, n. 6, p. $1307-1314,2004$.

POMPELLI, M. F.; BARATA-LUÍS, R. M.; VITORINO, H. S.; GONÇALVES, E. R.; ROLIM, E. V.; SANTOS, M. G.; ALMEIDACORTEZ, J. S.; ENDRES, L. Photosynthesis, photoprotection and antioxidant activity of purging nut under drought deficit and recorery. Biomass \& Bioenergy, Aberdeen City, v. 34, n. 8, p. 1207-1215, 2010a.

POMPELli, M. F.; MARTINS, S. C. V.; ANTUNES, W. C.; CHAVES, A. R. M.; DAMATTA, F. M. Photosynthesis and photoprotection in coffee leaves is affected by nitrogen and light availabilities in winter conditions. Journal of Plant Physiology, Tübingen, v. 167, n. 13, p. 1052-1060, 2010b.

POORTER, L.; ARETS, E. J. M. M. Light environment and tree strategies in a Bolivian tropical moist forest: an evaluation of the light partitioning hypothesis. Plant Ecology, Dordrecht, v. 166, n. 2 , p. 295-306, 2003.

RAMALHO, J. C.; PONS, T. L.; GROENEVELD, H. W.; AZINHEIRA, H. G.; NUNES, M. A. Photosynthetic acclimation to high light conditions in mature leaves of Coffea arabica $\mathrm{L}$.: role of xanthophylls, quenching mechanisms and nitrogen nutrition. Australian Journal of Plant Physiology, Tübingen, v. 27, n. 1, p. 43-51, 2000.

RAMALHO, J. C.; PONS, T. L.; GROENEVELD, H. W.; NUNES, M. A. Photosynthetic responses of Coffea arabica leaves to a shortterm high light exposure in relation to $\mathrm{N}$ availability. Physiologia Plantarum, Lund, v. 101, n. 1, p. 229-239, 1997.

RAMALHO, J. C.; QUARTIN, V. L.; LEITÃO, E.; CAMPOS, P. S.; CARELLI, M. L. C.; FAHL, J. I.; NUNES M. A. Cold acclimation ability and photosynthesis among species of the tropical Coffea genus. Plant Biology, Hoboken, v. 5, n. 6, p. 631-641, 2003.

REYNOLDS, E. S. The use of load citrate at a high $\mathrm{pH}$ as an electronopaque stain in electron microscopy. The Journal of Cell Biology, New York, v. 17, n. 4, p. 208-212, 1963.

RONCHI, C. P.; DAMATTA, F. M.; BATISTA, K. D.; MORAES, G. A. B. K.; LOUREIRO, M. E.; DUCATTI, C. Growth and photosynthetic down-regulation in Coffea arabica in response to restricted root volume. Functional Plant Biology, Clayton South Vic, v. 33, n. 11, p. 1013-1023, 2006.

RUBIO-DE-CASAS, R.; PÉREZ-CORONA, E.; MANRIQUE, E.; QUINTANA, J. R.; GARCÍA-VERDUGO, C.; BALAGUER, L. Field patterns of leaf plasticity in adults of the long-lived evergreen Quercus coccifera. Annals of Botany, Oxford, v. 100, n. 2, p. 325334, 2007.

SCHAFFER, A. A.; LIU, K. C.; GOLDSHMIDT, E. E.; BOYER, C. D.; GOREN, R. Citrus leaf chlorosis induced by sink removal: starch, nitrogen and chloroplast ultrastructure. Journal of Plant Physiology, Tübingen, v. 124, n. 1-2, p. 111-122, 1986.

SIMS, D. A.; PEARCY, R. W. Photosynthetic characteristics of a tropical forest understorey herb, Alocasia macrorrhiza, and a related crop species, Colocasia esculenta, grown in contrasting light environments. Oecologia, Heidelberg, v. 79, n. 1, p. 53-59, 1989.

TERASHIMA, I.; HANBA, Y. T.; TAZOE, Y.; VYAS, P.; YANO, S. Irradiance and phenotype: comparative eco-development of sun and shade leaves in relation to photosynthetic $\mathrm{CO}_{2}$ diffusion. Journal of Experimental Botany, Oxford, v. 57, n. 2, p. 343-354, 2006.

VALLADARES, F.; ARRIETA, S.; ARANDA, I.; LORENZO, D.; SANCHEZ-GOMEZ, D.; TENA, D.; SUÁREZ, F.; PARDOS, J. A. Shade tolerance, photoinhibition sensitivity and phenotypic plasticity of Ilex aquifolium in continental Mediterranean sites. Tree Physiology, Victoria, v. 25, n. 8, p. 1041-1052, 2005.

VALLADARES, F.; WRIGHT, J. S.; LASSO, E.; KITAJIMA, K.; PEARCY, R. W. Plastic phenotypic response to light of 16 congeneric shrubs from a Panamanian rainforest. Ecology, New York, v. 81, n. 7, p. 1925-1936, 2000.

VERHOEVEN, A. S.; DEMMIG-ADAMS, B.; ADAMS III, W. W. Enhanced employment of the xanthophyll cycle and thermal dissipation in spinach exposed to high light and $\mathrm{n}$ stress. Plant Physiology, Bethesda, v. 113, n. 3, p. 817-824, 1997.

WITKOWSKI, E. T.; LAMONT, B. B. Leaf specific mass confounds leaf density and thickness. Oecologia, Heidelberg, v. 88, n. 4, p. 486493, 1991

WRIGHT, S. J.; MULLER-LANDAU, H. C.; CONDIT, R.; HUBBELL, S. P. Gap-dependent recruitment, realized vital rates and size distributions of tropical trees. Ecology, New York, v. 84, n. 12, p. 3174-3185, 2003. 